УДК 81.161.2’25:821.111-31Пратчетт

DOI https://doi.org/10.26661/2414-1135-2021-83-4

\title{
ОСОБЛИВОСТІ СТВОРЕННЯ ТА ПЕРЕКЛАДУ АНТОНОМАЗЙ У РОМАНІ ТЕРРІ ПРАТЧЕТТА «КРАДІЙ ЧАСУ»
}

\author{
Бережна М. В. \\ кандидат філологічних наук, \\ доиент кафедри перекладу та слов'янської філологї, \\ заступник декана факультету іноземних мов \\ Криворізький державний педагогічний університет \\ просп. Гагаріна, 54, Кривий Ріг, Дніпропетровська область, Украӥна \\ orcid.org/0000-0002-3345-256X \\ margaret.berezhna@gmail.com \\ Грецька Д. О. \\ аспірантка кафедри теорії та практики перекладу з англійської мови \\ Запорізький національний університет \\ вул. Жуковського, 66, Запоріжжя, Украӥна \\ orcid.org/0000-0002-7622-1382 \\ dariyagretska@gmail.com
}

Ключові слова: антропонім, переклад імен власних, фентезі, алюзивні імена власні, міфоніми.
Роботи Террі Пратчетта мають значну популярність у всьому світі протягом тривалого часу. Його твори екранізуються провідними стримінг платформами, мають радіоадаптації й театральні постановки, засновані на сюжеті комп’ютерні ігри. Відносно недавно їх почали перекладати українською мовою; одним із перших вийшов переклад міні циклів про Смерть із серії «Дискосвіт». Відповідно, і робіт, присвячених українському перекладу, наразі немає, що зумовлює актуальність роботи. У цілому творчість Т. Пратчетта досліджується досить давно, хоча в основному розвідки стосуються більше культурологічних i літературознавчих аспектів, ніж мовознавчих. У статті маємо на меті визначити особливості створення та перекладу імен власних на прикладі роману Террі Пратчетта Thief of Time. Методом наскрізної вибірки з роману загальним обсягом 357 сторінок і його перекладу українською мовою отримано 85 антономазій з відповідниками. У результаті дослідження встановлено, що більшість прикладів імен власних є алюзивними, що перегукується 3 висновками наявних робіт, які досліджували особливості авторського стилю й інтертекстуальність у роботах Террі Пратчетта. Решта прикладів належить до промовистих імен власних і неускладнених додатковим смислом антропонімів. Такі результати підтверджують гіпотезу, що у фентезійних творах постмодерністських авторів імена власні переважно $\epsilon$ алюзивними та характеристичними. Серед прикладів виокремлюємо значну кількість міфонімів, що зумовлено сюжетом твору. Цікавим у досліджуваному романі $\epsilon$ те, що міфологічні персонажі олюднюються автором, унаслідок чого отримують імена загальновживаного антропонімікону. Для перекладу імен власних українською мовою переважно використовуються калька та практична транскрипція, рідше - функціональна заміна й морфограматична модифікація. Варто також відзначити, що для перекладу багатокомпонентних імен власних перекладач, як правило, застосовує декілька перекладацьких трансформацій водночас. 


\title{
THE PECULIARITIES OF CREATION AND TRANSLATION OF PROPER NAMES IN THE NOVEL THIEF OF TIME BY TERRY PRATCHETT
}

\author{
Berezhna M. V. \\ Candidate of Philological Sciences, \\ Associate Professor at the Department of Translation and Slavic Philology \\ Kryvyi Rih State Pedagogical University \\ Haharina Ave, 54, Kryvyi Rih, Dnipropetrovsk region, Ukraine \\ orcid.org/0000-0002-3345-256X \\ margaret.berezhna@gmail.com
}

Hretska D. O.

Postgraduate Student at the Department of Theory and Practice of English Translation

Zaporizhzhia National University

Zhukovskoho str., 66, Zaporizhzhia, Ukraineorcid.org/0000-0002-7622-1382

dariyagretska@gmail.com

Key words: anthroponym, translation of proper names, fantasy, allusive proper names, mythonyms.

\begin{abstract}
The novels by Terry Pratchett have been extremely popular around the world for a long period of time. His works are being adapted into TV and Amazon series, radio and theater plays; computer games are based on their plot. The translation of the novels into Ukrainian has recently begun; one of the first completed translations is the storyline about Death from the Discworld series. Thus, there are no researches focused on the Ukrainian translation, which determines the relevance of the presented work. In general, Pratchett's novels have been studied for a long time, although those studies mainly concern cultural or literature aspects rather than linguistic ones. In this paper, we aim to determine the peculiarities of the creation and translation of the proper names used in the novel Thief of Time by Terry Pratchett. Using the end-to-end sampling method, we selected 85 antonomasias from the novel Thief of Time with the total volume of 357 pages and their translations into Ukrainian. The results demonstrate that the majority of the proper names are allusive, which echoes the findings of the previous works exploring the features of Terry Pratchett's writing style and the intertextuality in his novels. The rest of the examples belong to the groups of characteristic names and anthroponyms without any additional meaning. These results support the idea that in the fantasy fiction by postmodernist authors proper names are mostly allusive and characteristic. Among the collected examples, we distinguish a sufficient number of mythonyms, which is predetermined by the plot. Of special interest is the author's tendency to humanize mythological characters by giving them names fom commonly used anthroponymicon. Calque and practical transcription are the most numerous ways to translate the proper names into Ukrainian. The insignificant rest is rendered by functional replacement and morphogrammatic modification. We also demonstrate that the translator tends to apply several translation transformations simultaneously to translate some multicomponent proper names.
\end{abstract}

Постановка проблеми. Твори Террі Пратчетта мають значну популярність у всьому світі, але лише відносно нещодавно їх почали перекладати українською мовою. Мініцикл про Смерть із серії «Дискосвіт» став одним із перших циклів, переклад якого завершено повністю. Одним із викликів, які постають перед перекладачем, є переклад імен власних, які, окрім номінативної функції, виконують і характеристичну, виступаючи засобом формування образів персонажів. Робіт, присвячених українському перекладу роману «Крадій часу», наразі немає, що зумовлює актуальність розвідки.

Мета роботи - визначити особливості створення антономазій у романі Террі Пратчетта Thief 
of Time та способи їх перекладу українською мовою.

Об'єкт роботи - 85 антономазій, вилучених методом наскрізної вибірки з роману Thief of Time (загальним обсягом 357 сторінок) і їх переклад українською мовою Віктора Морозова (444 сторінки).

Предмет - особливості створення антономазій у сучасних англомовних фентезійних творах $\mathrm{i}$ ïx відтворення українською мовою.

Історія досліджень. Дослідженням імен власних як авторських оказіоналізмів займалися такі науковці, як Є.Г. Ковалевська, О.В. Суперанська, А.І. Іманалієва, О.В. Ребрій, В.В. Виноградов, Е.І. Ханпіра, Д.І. Єрмолович, Н.Г. Бабенко, Ю.Н. Несветайло, В.М. Калінкін, а також Дж. Алгео й А. Алгео. Відзначаючи унікальність і специфіку онімної лексики, дослідники виділяють низку специфічних рис художніх онімів:

1) художні оніми денотативно співвіднесені не з реальними людьми, а зі створеними автором образами (О.В. Суперанська, В.М. Калінкін);

2) художні оніми вторинні відносно реальних онімів і детерміновані конкретною мовою, «вони створюються за моделями імен реальних або нереальних предметів з урахуванням належності їх до певного ономастичного поля» [9, с. 148];

3) крім номінативної функції, художні оніми виконують характеристичну і стилістичну функції;

4) художні оніми відрізняються рухливістю семантики та динамічністю змісту, нестійкістю щодо належності до ономастичної або апелятивної лексики;

5) художні оніми $є$ національно специфічними й детермінованими культурою. Вони набувають свого значення не тільки в контексті художнього твору, а й у контексті мовної, ономастичної системи певної лінгвокультури та з часом отримують національно-культурні конотації.

Особливості перекладу імен власних у творах фентезі досліджували такі автори, як О.М. Шапошник, О.В. Мазур, Е.П. Новицька й інші. Вони розглядали проблеми, з якими стикається перекладач, методи їх вирішення, а також особливості організації ономастикону в різних авторів.

Такі мовознавці, перекладознавці та літературознавці, як Є.С. Канчура, Ю.В. Глюдзик, Ю.В. Курята, О.В. Касаткіна-Кубишкіна, М.Ф. Третьякова, І.А. Воробйова та інші, досліджували різні аспекти творчості Т. Пратчетта. В англомовному науковому просторі існує багато досліджень робіт автора, які являють собою як повні гідиз творчості Т. Пратчетта, так й окремі дослідження, в основному культурологічні або літературознавчі. Наприклад, є роботи про наративи, наявні в його творчості, і риси постмодернізму, які простежуються.
Окремо можемо виділити досить повний огляд його творів, виконаний Ендрю М. Батлером (Andrew M. Butler) у книзі Terry Pratchett, у якій автор розглядає основні сюжетні лінії та головних персонажів, орієнтуючи читача в хитросплетіннях творів, які налічують десятки романів, енциклопедії, п’єси, адаптації, календарі, щоденники, радіосеріал, комп'ютерні ігри, альбоми 3 треками за мотивами Дискосвіту й багато іншого. Це цілий всесвіт, створений однією людиною, утім настільки продуманий і детальний, що легко можна повірити в його реальність десь в іншому паралельному всесвіті [2].

Прояви постмодерністської пародії в серії романів Т. Пратчетта про Дискосвіт досліджує Крістофер Браянт (Christopher Bryant). «Жанр фентезі та, як наслідок, романи Пратчетта, часто сприймають як легке дитяче читво, не варте критичної уваги. Насправді багато концепцій і посилань із серії Дискосвіту надзвичайно складні, у результаті чого їх можна оцінити на двох рівнях: діти можуть насолоджуватися книгами про веселі фантастичні пригоди, а дорослі зможуть осягнути глибші ідеї Пратчетта. Крім того, з точки зору постмодерну немає жодних підстав приділяти менше уваги цим романам, ніж будь-яким іншим художнім творам: бар'єри між «високою» i «низькою» культурою більше не актуальні...», - пише автор [3].

Інтертекстуальність - це ще одна яскрава особливість робіт Т. Пратчетта. Ю.В. Курята, О.В. Касаткіна-Кубишкіна розглядають цей аспект як полеміку автора із Шекспіром, асоціації з «білим знанням», які знайшли вираження у власних іменах, трансформованих цитатах та алюзіях; проводять лінгвістичний і культурологічний аналіз тексту. «У романах Террі Пратчетта відбувається реалізація базового гасла постмодерну - «світ як текст» - на матеріалі вторинного світу, створеного засобами авторської фантазії, що спирається на інтертекстуальну свідомість сучасного читача та здатність тексту впливати на вибудову реальності», - підсумовують працю автори [7, с. 105].

Серед досліджень творів Террі Пратчетта в українському науковому просторі передусім хотілося б виділити роботу Ю.В. Глюдзик, яка досліджує переклад імен власних у романі Reaper man із того ж циклу про Смерть. Дослідниця, розглядаючи прихований сенс, вкладений автором у характеристичні імена власні та їх структуру, зазначає, що «основними техніками творення власних назв $€$ однокомпонентна номінація, двокомпонентна номінація, неонімічна номінація» [5, с. 27]. Авторка робить висновок, що «Т. Пратчетт був надзвичайно скрупульозним при створенні антропоетонімів для своїх книг. Усі вони символічні, 
відмінно підходять до своїх персонажів і мають на меті допомогти читачам «поринути» в атмосферу Дискосвіту» [5, с. 28].

Виклад основного матеріалу. У роботі розглядаємо оніми 3 роману Т. Пратчетта «Крадій часу» та способи перекладу цих одиниць українською мовою. Масив прикладів складається 3 85 імен власних, які поділено на дві групи: імена власні персонажів та імена колективні, як-от: назви груп, гільдій, об'єднань. Розглянемо першу групу - антропоніми. Тут бачимо імена власні, які утворені різними шляхами. Перший спосіб це імена власні загального антропонімікону, які автор використовує для позначення фонових, епізодичних персонажів, роль яких порівняно неважлива для сюжету. Другий спосіб - це комбінування узуальних основ із продуктивними суфіксами та префіксами для утворення оказіональних характеристичних імен власних. Третій спосіб - перехід загальновживаних іменників до розряду імен власних. Четвертий спосіб (порівняно нечисленний) - утворення імен власних на основі фразових епітетів. Окрему групу становлять алюзивні імена власні, які базуються на експліцитному чи імпліцитному посиланні до відомих історичних чи культурних постатей або явищ.

Загалом результати проведеного дослідження перегукуються 3 висновками інших дослідників, які ділять ономастичний простір на імена загального антропонімікону, імена характеристичні й імена алюзивні. Варто зазначити, що, хоча фразові епітети не $є$ чимось новим для гумористичного фентезі та англомовних художніх творів загалом, утворення імен власних на основі фразових епітетів $є$ відносно новою тенденцією.

Розглянемо ці групи на прикладах. Розпочнемо $з$ імен власних, що $є$ алюзією на історичних осіб: Lu-Tze [4, с. 13] / Лу-Тзе [8, с. 92]. У цьому випадку бачимо антропонім, ім'я одного з головних персонажів, історичного монаха. Цей персонаж $\epsilon$ алюзією на древньокитайського філософа Лао-Цзи, основоположника даосизму й автора «Дао де Цзин». У деяких трактуваннях релігійних шкіл він навіть уважається божеством, «одним із трьох чистих». Алюзія простежується в багатьох аспектах сюжету та біографії персонажа. Наприклад, антропоморфна сутність Хаос указує на те, що Лу-Тзе є його «створінням». Як і ЛаоЦзи, Лу-Тзе жив скромно, був прибиральником у монастирі, усе, чого навчився, він навчився підмітаючи. Серед Історичних монахів він був людиною легендарною, і часом послушники не могли повірити, що згорблений старий насправді є тим героєм, про якого розповідають легенди. Також у романі є сатирична алюзія на книгу Лао-Цзи «Дао де Цзин» (Книга шляху й гідності), адже шлях Лу-Тзе називається «Шлях Пані Космопіліт, здаю квартири в Анк-Морпорку недорого». Інші Історичні Монахи не розуміли іiі суті, а Лу-Тзе й не намагався пояснювати.

$\mathrm{y}$ перекладі бачимо варіант, отриманий за допомогою практичної транскрипції. Оскільки співзвуччя з іменем Лао-Цзе зберігається, уважаємо такий еквівалент адекватним.

Наступний приклад цієї групи: But research turned up the fact that the woman in the picture Woman Holding Ferret by Leonard of Quirm was considered the epitome of beauty, and so they'd based Lady LeJean on that $[4$, c. 76] / Але завдяки дослідженню з'ясувалося, що жінка на картині Леонарда-з-Квірма «Дама, яка тримає тхора» вважалася втіленням краси, тому на ії основі вони й виготовили образ леді ЛеГіжон [8, с. 199]. Тут бачимо очевидну алюзію до Леонардо да Вінчі та його картину «Пані $з$ горностаєм». Вона $є$ досить відомим твором мистецтва, тож аналогії досить асоціативні. Основна перекладацька трансформація, використана тут, - це калька.

Наступною групою в корпусі прикладів виділяємо імена характеристичні: Myria (Unity) Le Jean [4, с. 19] / Mipia (Сдиність) ЛеГіжон [8, с. 360]. Тут бачимо ім'я власне, яке поєднує алюзію та гру слів. Названий персонаж належить до Аудиторів, міфічних створінь, які займаються обліком усього, що є у Всесвіті. Вічні спостерігачі за часом і простором, вони ненавиділи життя, бо воно означало й смерть також. Перший компонент імені Myria $\epsilon$ скороченням від грецького myriad, яке перекладається як «десять тисяч, багато». Другий компонент прізвище Le Jean $є$ видозміненим іменником legion «легіон, багато». Це біблійна алюзія на випадок, коли Ісус вигнав демона на ім'я Легіон. Таким чином, ім'я і прізвище утворюють гру слів. Утім це прогнозовано, оскільки Аудитори вірили, що ім'я має позначати те, чим $є$ насправді предмет найменування, виражати його сутність. Третій компонент Unity є другим іменем для персонажа, оскільки старе ім'я її не влаштовувало. Це ім'я можна перекласти як «єдність, згода, гармонія». Можливо, Сьюзен мала на увазі досягнення гармонії між її сутністю Аудитора й людським тілом, котре нав'язувало їй дивні бажання і думки, а також містить певне віддзеркалення звичаю Аудиторів цуратися всього, що хоч якось пов'язано 3 індивідуальністю, адже вони завжди використовували тільки займенник «ми» і знищували тих Аудиторів, які подавали хоч найменші ознаки прояву індивідуальності. Аудитори - цілісне створіння в кількох тілах.

У перекладі бачимо такі трансформації як практична транскрипція (Myria «Міріа») та калька (Le Jean «ЛеГіжон», Unity «Єдиність»). Хоча перший компонент утрачає своє характеристичне значення, алюзія зберігається і $є$ зрозумілою 
принаймні частині аудиторії як оригіналу, так i перекладу. Оскільки такий відповідник у цілому відтворює номінативну й алюзивну функції оригіналу, уважаємо переклад вдалим.

Перейдемо до іншого прикладу: Lobsang Ludd (born Newgate Ludd) [4, c. 19] / Ньюгейт Лудд Лобсанг [8, с. 81]. Тут бачимо антропонім, ім'я одного з головних героїв, брата-близнюка Jeremy Clockson. За сюжетом твору, це одна душа, ніби розділена на два тіла, котрі живуть не підозрюючи одне про одного, незалежно одне від одного. Це $\epsilon$ певною алегорією на Час, який у баченні автора щосекунди знищує старий світ у минулому й відтворює його в майбутньому, тобто має місце така собі двоіпостасність часу. Саме це й відбивається в імені персонажа Lobsang, оскільки перша частина походить від lobbing, одне зі значень якого «розділення навпіл, розсічення». Друга ж частина sang походить від китайського «сан», що означає «пан», що цілком зрозуміло, адже герой стає Історичним Монахом (певна алюзія на буддистських монахів) та отримує таке ім'я саме в монастирі, де показує свої незвичні здібності до розтинання часу. Так отримуємо дослівний переклад «Пан, що розтинає час». Прізвище Ludd у самому тексті роману пояснюється як таке, що дається всім дітям, підкинутим під двері Гільдії крадіїв. Звідси власне й вроджене ім'я Newgate за назвою воріт, під якими знайшли кошик із дитиною. Воно також утворене сполученням двох основ New i gate, що можна перекласти як «нова брама».

У перекладі бачимо використання практичної транскрипції. Певна частина смислу втрачається, але це компенсується контекстом (походження прізвища Ludd пояснюється в тексті як «розділені втілення» головного героя). Основні характеристичні функції, такі як алюзія на китайських буддистських монахів, збережені. Тому вважаємо цей варіант перекладу адекватним.

Перейдемо далі: Nanny Ogg [4, c. 91] / Тітуня Oпr $[8$, с. 230]. Тут бачимо антропонім, ім'я повитухи й відьми. Існує декілька версій походження iii імені. Наприклад, вона називає свою хатину Tir Nanny Ogg, що можна розглядати як варіант давньоірландського Tírnan Óg «Священний острів». Для цього персонажа фраза має сенс, адже вона змушувала своїх численних невісток працювати на неї, наче служниць, а сама жила, наче богиня. Можна продовжити проводити аналогії $з$ давньоірландською і щодо іiі імені. Наприклад, давньоірландський огамічний алфавіт називався Ogham, a в одній із книг персонаж стверджує, що це і1і предки вигадали давню мову - Oggham. Утім сам автор в одному 3 інтерв'ю стверджував, що ім'я цього персонажа взято від назви телефонної книги. Тому питання лишається без однозначної відповіді, проте деякі збіги, на нашу думку (зокрема 3 давноірландськими коренями й значеннями), навряд чи є збігами.

У перекладі бачимо, що ім'я передано транскрипцією. У результаті виникають асоціації 3 таким фольклорним персонажем кельтської міфології як огр, відомим своєю силою, непоказною зовнішністю й низьким рівнем інтелекту, знайомим більшості молодшого покоління завдяки фільму «Гаррі Поттер та філософський камінь», анімаційному фільму «Шрек» і численним комп'ютерним іграм. Уважаємо, що такий асоціативний ряд формує неправильне враження про мудру повитуху.

Розглянемо ще один приклад: Jeremy Clockson [4, с. 75] / Джеремі Дзигар [8, с. 20]. Тут бачимо антропонім, ім'я головного персонажа, який і $€$ Крадієм часу. Перший компонент ім'я Jeremy $\epsilon$ алюзією на одного з великих пророків - Ієремію. Так ім'я визначає особливу долю героя. Другий компонент - прізвище, яке можна дослівно перекласти як «син годинника». За сюжетом роману, персонаж $є$ сином антропоморфної сутності Часу. Отже, воно цілком себе виправдовує.

У перекладі бачимо, що ім'я передано практичною транскрипцією, а прізвище - функціональним аналогом. Оскільки принаймні другий елемент виконує певну характеристичну функцію, частково відтворюючи закладений автором смисл, уважаємо такий переклад у цілому адекватним. Утім варто відзначити, що сучасне покоління читачів скоріше за все не знає, що Дзигар - це застаріла назва професії годинникаря, унаслідок чого можуть виникати хибні асоціації. Також варто зазначити, що часом навіть адекватний переклад не здатен передати всього смислового навантаження імені власного. Наприклад, алюзія на пророка Ієремію втрачається в результаті використання транскрибованого відповідника. Однак навіть історичний відповідник «Іеремія» навряд чи $б$ нагадав про біблійного персонажа сучасному середньостатистичному читачу, який досить поверхово знайомий зі Старим Заповітом.

Наступна група прикладів ілюструє іменники, які переходять у розряд імен власних. Найбільш характерними та значущими $є$ такі приклади, як Kaos «Хаос», Time «Час», Death «Смерть». У творі вони позначають антропоморфні сутності, які існують завдяки вірі людей у них. У творах Террі Пратчетта вони «олюднюються» ій мають людські риси характеру. Перекладені ці імена калькуванням.

Цікавими також $є$ імена, утворені на основі фразового епітета. Наприклад, Воу Most Likely to Be Killed One Day By His Wife ra Get Out of The Way. Перший приклад - це ім'я епізодичного персонажа, який використовується ситуативно й однократно. У перекладі бачимо відповідник 
«Хлопець, Якого Найвірогідніше Приб’є Одного Дня Власна Дружина», отриманий калькуванням. Другий приклад - прізвисько одного з головних героїв, Лу-Тзе. Оскільки сам він надавав перевагу скромному званню підмітальника, люди часто зверталися до нього саме так - «Геть 3 дороги». У цьому варіанті перекладу теж бачимо кальку.

Інша група, яку ми розглянемо в рамках роботи, - це імена власні, які належать до загального антропонімікону: Penelope, Melanie, Vincent, Joan, Gordon, Albert, Miranda, Stephanie, Samuel. Усі вони перекладаються за допомогою історичного відповідника (Пенелопа, Вінсент, Джоан, Гордон, Альберт, Міранда, Самуїл) або морфограматичної модифікації (Меланія, Стефанія). Морфограматична модифікація допомагає урівноважити іншомовні імена тими, які є ближчими читачу перекладу, i таким чином знайти «золоту середину» між одомашненням та очуженням. Зазначимо, що такими іменами називаються переважно епізодичні персонажі, які слугують лише «фоном» і не виконують сюжетоформуючої ролі.

Перейдемо до імен колективних. Наприклад, The Auditors [4, с. 139]/Аудитори [8, с. 106]. Тут бачимо антономазію - алюзивне ім'я власне, котре позначає цілий клас об'єктів. На початку книги епіграфом є теза, у якій стверджується, що для того, аби Всесвіт існував, він має бути видимим: від англ. Observable Universe «Спостережуваний Всесвіт». Аудитори $\epsilon$ істотами, які, по суті, навіть не $\epsilon$ живими, але існують для того, аби спостерігати за цим Всесвітом, щоб він існував. Аудитори ненавиділи будь-який прояв індивідуальності, бо були переконані, що індивідуальність веде до життя, а життя - до смерті. Отже, якщо ти не живеш, а існуєш, то й не помреш. Вони не використовують навіть займенник «я», тільки «ми». Таким чином, виходить, що істот кілька, а ім'я одне на всіх як позначення того, що вони становлять єдину сутність. Ці істоти є певною пародією на бюрократичний апарат - безликий, із ненавистю до всього живого. В українському перекладі бачимо калькування, яке передає задум автора, зберігає асоціацію з бюрократією.

Також до групи відносимо назви гільдій (Guild of Historians, Guild of Clockmakers, Guild of Thieves etc.), релігійних орденів (Order of Wen, Listening Monks, Brothers of Cool, the Balancing Monks, the History Monks, the Fifth Djim field agents, Sweepers etc.) або узагальнені назви груп, як-от Little Minds. У перекладі цих одиниць найчастіше бачимо кальку в поєднанні 3 деонімізацією як стосовно назв гільдій (Гільдія істориків, Гільдія годинникарів, Гільдія злодіїв), так і стосовно релігійних орденів (Орден Колина, ченці-слухачі, Брати Незворушності, балансуючі ченці, історичні ченці, польові агенти П'ятого Д'їма, підмітальники) та узагальнених назв (юні мізки).
Можна відзначити певну тенденцію, адже, чим продуктивнішим $\epsilon$ спосіб утворення імені власного, тим вищий шанс, що ім'я буде перекладатися за допомогою кальки, практичної транскрипції або історичного відповідника. I навпаки, якщо ім'я власне створене за непродуктивними моделями, тим частіше використовуються інші методи, як-от: функціональні аналоги або онімні заміни.

Також зазначимо, що головні персонажі часто мають декілька варіантів імені: Lu-Tze, Get Out of The Way або little bald wrinkly smiling men. Це все імена вчителя головного героя твору. У самого ж головного героя теж як мінімум три імені: Jeremy Clockson, Lobsang Ludd i Newgate Ludd, які ми розглянули вище. Смерть також має дві іпостасі Death «Смерть» та Death of Rats «Смерть Щурів», а в інших книгах серії отримує додаткові варіанти імені. Ще одна дійова особа - антропоморфне втілення Хаосу також має подвійне ім'я: Kaos «Хаос» i Ronald Soak, Dairyman «Рональд Соак, молочар».

Висновки. Серед узагальнень, отриманих у ході дослідження: 1) головні персонажі в романі T. Пратчетта мають алюзивні (41 випадок) або характеристичні імена власні (33 одиниці); 2) імена епізодичних персонажів належать до загального антропонімікону (11 випадків); 3) головні персонажі мають по декілька варіантів імені (часто ім'я, прізвище, прізвисько, ситуативне прізвисько); 4) більшість імен власних $€$ двокомпонентними; незначна кількість $€$ одно- або багатокомпонентними; 5) антропоніми становлять більшість прикладів (57), далі міфоніми (14) і колективні назви (14), що обумовлено сюжетом: головними героями $\epsilon$ звичайні люди та надприродні сутності; 6) серед алюзивних імен переважають алюзії на реально існуючі явища (27 випадків), алюзії на творчість інших письменників (8 прикладів) і на історичних осіб (6 одиниць); 7) серед перекладацьких трансформацій переважає калька (45 випадків), адже перекладач намагається зберегти смисл імені оригіналу; далі практична транскрипція (34 приклади), що можна пояснити вибраною стратегією перекладу - очуженням; далі функціональна заміна (8 випадків) i морфограматична модифікація (5 одиниць); 8) при перекладі дво- й багатокомпонентних імен власних перекладач застосовує декілька перекладацьких трансформацій одночасно.

Перспективи подальших досліджень полягають у вивченні ономастикону інших романів T. Пратчетта, зокрема серії книг, присвячених Смерті, i їх перекладів українською мовою, 3 метою виконання порівняльного аналізу способів створення імен власних, їх загальної типології, а також особливостей і загальних тенденцій їх відтворення в українському перекладі. 


\section{ЛІТЕРАТУРА}

1. Andersen Dorthe. Bewitching Writing. An Analysis of Intertextual Resonance in the Witchsequence of Terry Pratchett's Discworld, Aalborg, 2006. $91 \mathrm{p}$.

2. Andrew M. Butler Terry Pratchett. Chicago : Independent Publishers Group, 2001. 78 p.

3. Bryant Christopher. Postmodern Parody In The Discworld Novels of Terry Pratchett. Dissertation presented for the degree of Bachelor of Arts, Single Honours in English, Faculty Of Arts And Education.University Of Plymouth The L-Space Web: Analysis. URL: http://www.lspace.org/ books/analysis/christopher-bryant.html. (дата звернення: 18.07.2021).

4. Pratchett T. Theif of time. London : Gollancz, $2001.357 \mathrm{p}$.

5. Глюдзик Ю.В. Антропоетоніми у творчості Террі Пратчетта. Матеріали щорічної підсумкової конф. професорсько-викладацького складу факультету іноземної філології ДВНЗ «Ужгородський наиіональний університет», м. Ужгород, 26 лют. 2019 року. Ужгород : ТОВ «Поліграфцентр «Ліра», 2019. С. 26-29.

6. Канчура С. Інтертекстуальність як риса поетики жанру фентезі (на прикладі романів Террі Пратчетта). Питання літературознавства. 2008. № 77. C. 205-209.

7. Курята Ю.В., Касаткіна-Кубишкіна О.В. Лінгвокультурне коментування літературної спадщини Террі Пратчетта (на основі серії Плаский світ). Наукові записки Національного університету "Острозька академія». Серія «Філологічна». 2014. № 46. С. 103-105.

8. Пратчетт Т. Крадій часу: роман / переклад 3 англ. Віктора Морозова. Львів : Видавництво Старого Лева, 2021. 444 с.

9. Суперанская А.В. Общая теория имени собственного. Москва : Наука, 1973. 367 с.

\section{REFERENCES}

1. Andersen Dorthe (2006) Bewitching Writing. An Analysis of Intertextual Resonance in the
Witchsequence of Terry Pratchett's Discworld. Aalborg: Aalborg University.

2. Andrew M. Butler (2001) Terry Pratchett. Chicago: Independent Publishers Group.

3. Bryant Christopher Postmodern Parody In The Discworld Novels of Terry Pratchett. Dissertation presented for the degree of Bachelor of Arts, Single Honours in English, Faculty Of Arts And Education.University Of Plymouth The L-Space Web: Analysis. URL: http:// www.lspace.org/books/analysis/christopherbryant.html (accessed 18 July 2021).

4. Pratchett T. (2001) Theif of time. London: Gollancz.

5. Hliudzyk, Yu. V. (2019) Antropoetonimy u tvorchosti Terri Pratchetta [Anthropoetonyms in Terry Pratchett's works]. Proceeding of the annual final conference of the Department of Foreign Philology of Uzhhorod National University (Ukriane, Uzhhorod, February 26, 2019), Uzhhorod : Polygraph Center Lira, pp. 26-29.

6. Kanchura Ye. (2008) Intertekstualnist yak rysa poetyky zhanru fentezi (na prykladi romaniv Terri Pratchetta) [Intertextuality as a feature of the poetics of the fantasy genre (on the example of Terry Pratchett's novels)]. Pytannia literaturoznavstva, no. 77, pp. 205-209.

7. KuriataYu.V.,Kasatkina-KubyshkinaO.V.(2014) Linhvokulturne komentuvannia literaturnoi spadshchyny Terri Pratchetta (na osnovi serii Plaskyi svit] [Linguo-cultural commenting on the literary heritage of Terry Pratchett (based on the series Flat World)]. Naukovi zapysky Natsionalnoho universytetu Ostrozka akademiia. Seriia: Filolohichna, no. 46, pp. 103-105.

8. Pratchett T. (2021) Kradii chasu [Theif of time]. Lviv: Vydavnytstvo Staroho Leva (in Ukrainian).

9. Superanskaya A. V. (1973) Obshchaya teoriya imeni sobstvennogo [General theory of proper name]. Moscow: Nauka (in Russian). 